\title{
Outdoor detection and visualization of hailstorm damages of photovoltaic plants
}

\author{
Wolfgang Muehleisen ${ }^{a}{ }^{*}$, Gabriele C. Eder ${ }^{b}$, Yuliya Voronko ${ }^{b}$, Markus Spielberger ${ }^{c}$, \\ Horst Sonnleitner ${ }^{\mathrm{d}}$, Karl Knoebl ${ }^{\mathrm{e}}$, Rita Ebner ${ }^{\mathrm{f}}$, Gusztav Ujvari ${ }^{\mathrm{f}}$, Christina Hirschl ${ }^{\mathrm{a}}$ \\ a CTR Carinthian Tech Research AG, Europastr. 12, 9524, Villach/St.Magdalen, Austria \\ b OFI Austrian Research Institute for Chemistry and Technology, Franz Grill Straße 5, 1030, Vienna, Austria \\ c PVSV e.U., Unterer Markt 7, 9334, Guttaring, Austria \\ d ENcome Energy Performance GmbH, Lakeside B08, A-9020, Klagenfurt, Austria \\ e University of Applied Science Vienna, Höchstädtplatz 6, 1200, Vienna, Austria \\ ${ }^{\mathrm{f}}$ AIT Austrian Institute of Technology GmbH, Giefinggasse 2, 1210 Vienna, Austria
}

\section{A R T I C L E I N F O}

\section{Article history:}

Received 31 July 2017

Received in revised form

30 October 2017

Accepted 4 November 2017

Available online 8 November 2017

Keywords:

Crystalline silicon

PV modules

Hail damage

Characterisation

\begin{abstract}
A B S T R A C T
Photovoltaic modules can experience damages of varying severity in the case of heavy hail storms. In the worst case, complete glass and solar cell breakage results in efficiency and security losses of the affected modules which therefore have to be replaced. However, there is a strong need to inspect the remaining modules directly in the field in order to assure no hidden damage. Three hail-affected photovoltaic plants in the south of Austria were investigated first with common standard methods like analysis of the plant monitoring data and thermography. Then, these plants were additionally investigated by novel nondestructive methods. With the aid of two innovative characterisation tools, outdoor electroluminescence and UV-fluorescence imaging, hail-induced damaging of solar cells can be detected even when the solar glass of the modules withstood the mechanical impact of the hailstorm and no damages are visible to the naked eye or well recognizable by thermography. The non-destructive, easy to handle and fast characterization technique UV-fluorescence imaging allows the detection and visualisation of hail induced cell damage. Modules showing partial cell breakage and/or micro cracks - as proven by outdoor electroluminescence measurements - and lead to a reduced electrical performance can be unequivocally identified.
\end{abstract}

() 2017 Elsevier Ltd. All rights reserved.

\section{Introduction}

Reliability and long term performance of Photovoltaic (PV) modules for warranted lifetimes of $20+$ years with a total yield loss not exceeding $20 \%$ are a crucial request of the market to allow for increasing implementation of photovoltaic technology as strong part in the renewable energy mix.

Several test procedures like IEC61215 or IEC61730 exist to ensure high product quality of PV modules at the manufacturing site. One of the most frequently used methods in the laboratory and

\footnotetext{
* Corresponding author.

E-mail addresses: wolfgang.muehleisen@ctr.at (W. Muehleisen), Gabriele.Eder@ ofi.at (G.C. Eder), Yuliya.Voronko@ofi.at (Y. Voronko), markus.spielberger@pvsv.at (M. Spielberger), Horst.Sonnleitner@en-come.com (H. Sonnleitner), karl.knoebl@ technikum-wien.at (K. Knoebl), Rita.Ebner@ait.ac.at (R. Ebner), Gusztav.Ujvari@ait. ac.at (G. Ujvari)
}

for quality insurance in the module production line is electroluminescence imaging. Electroluminescence provides information on the uniformity of the current flow in individual solar cells and whole modules and allows for detecting cell-cracks and disruptions in the electric connection system comprising of busbars, cell connectors and junction box.

However, once the modules are installed at the PV plant, besides monitoring the generated electrical power over time only limited characterisation methods are available to verify the faultless performance of individual PV-modules directly in the field. The most frequently used inspection method in the field is Infrared (IR)thermography with a portable camera which can detect thermal (e.g. hot spots or hot cells due to temporary shadowing or impurities) and some electrical failures like unconnected modules or strings or defective bypass diodes [1-4].

As several faults and defects can't be detected in the field by the well-established thermographic method, recently strong efforts 
were undertaken to develop innovative techniques like e.g. outdoor electroluminescence (EL) [5] and UV-fluorescence imaging [6-9] to provide PV-plant operators with a tool for improved nondestructive maintenance. Regular check-ups of the installed PVmodules appear necessary especially after extreme stress imposed by storm events, heavy snow loads or hail storms [10,11].

Although fluorescence effects of the aged and degraded polymeric PV-encapsulation materials were already detected by the group of Pern and Czanderna 20 years ago [12] only in the last years intensified interest to use this effect for a characterisation tool of weathered and aged PV-modules appeared. The characteristic fluorescence pattern of PV-modules obtained from the polymeric encapsulant upon irradiation with an ultraviolet (UV)-lamp contains manifold information connected with the (i) barrier properties of the backsheet used, (ii) degradation of the encapsulant, (iii) time and type of stress impact at the installation site and (iv) the integrity of the solar cells [13-15]. These effects and the fact that this method is fast, cheap and flexible allow UV-fluorescence imaging to be one of the most promising innovative inspection methods for installed PV-modules.

For the work presented, several PV-plants which experienced heavy hail storms were investigated. A decreased power-output after the stress event and numerous modules showing glass breakage were identified. After exchanging these obviously damaged modules, the question came up whether the hail storm also affected the performance of all other modules in the plant. Thus, innovative outdoor characterisation methods such as outdoor electroluminescence and UV-fluorescence imaging were chosen to non-destructively detect hidden hail storm induced damages of all modules in affected PV-plants. In order to prove the conclusions made upon the experimental data, the effect of hail impact on the degradation behaviour of modules was also simulated in the laboratory in accelerated ageing tests of test modules.

\section{Experimental \& methods}

\subsection{Description of the hail-affected PV-plants}

Three hail-affected PV plants in the south of Austria (Carinthia) were investigated. The distance over air of the 3 plants is approximately $10 \mathrm{~km}$. All three PV-systems comprise of standard glass/ backsheet modules installed on flat roofs. PV plant 3 is a research installation, PV plant 2 is a company owned plant on a shopping centre, and plant 1 is a company owned system installed on the roof on a production hall.

A heavy hail storm took place in this region in summer 2015 at the afternoon of the 8th of July. Hailstones with a diameter up to $40 \mathrm{~mm}$ dropped down on the PV-modules. After the hail storm, all three inspected power plants showed some modules with visible detectable damages (broken glass). The details for the plant construction and module types as well as the number of damaged modules after the hail storm are summarized in Table 1.

\subsection{Yield data evaluation}

For comparison, the monitoring data of all three power plants is analysed and the performance ratio (PR) for each plant calculated. The PR is the quotient of the actual measured yield (averaged per month) and the targeted yield (calculation based on irradiance measurements and the labelled module/system power) of the PV plant (IEC 61724) and is expressed within the paper in percent.

In addition, the relative yield (RY) of a hail affected and glass broken module compared to a healthy reference module is checked with a module fine monitoring system from Solar Edge at plant 3. It allows for a comparison of string performance ratio and energy yield per module. In addition, the behaviour of the glass-broken module is monitored over two years at plant 3 (Figs. 1 and 6).

As plant 1 has no own irradiation sensor, the irradiation data are taken from the nearby plant 2 (10 km distance). For all calculations whether PR or RY, a monthly average is used.

\subsection{Thermography (TG)}

Thermography is one of the common measurement techniques for inspecting photovoltaics plants as all sun illuminated PV modules emit infrared radiation. Thermographic cameras detect radiation in the long-infrared range of the electromagnetic spectrum and produce images of that radiation. The basic requirement for this measurement is sunlight of at least $600 \mathrm{~W} / \mathrm{m}^{2}$ [4] in order to generate measureable temperature differences for the evaluation of PV modules. The most important feature is the evaluation of the temperature homogeneity distribution within a module, as good working modules show equal $\left( \pm 2{ }^{\circ} \mathrm{C}\right)$ cells temperatures for all cells. All inspections are made with a high resolution standard infrared camera with a measurement range of 7-12 $\mu \mathrm{m}$ wavelengths. The camera (Testo 890) is equipped with a micro bolometer detector with a resolution of $640 \times 480$ Pixels.

\subsection{Twilight electroluminescence (TW-EL)}

Electroluminescence (EL) is an optical and electrical phenomenon in which a material emits light in response to the passage of an electric current or a strong electric field. When investigating PV modules, current is fed into a solar cell/module and radiative recombination of carriers causes light emission. The PV module string/modules are powered in forward direction and work as large „LED array“, which is emitting light in the near infrared range at $1100 \mathrm{~nm}$ (bandgap of $\mathrm{Si}$ ). For EL measurements it is important to have dark environment, thus, measurements are usually performed in a dark chamber of a laboratory. Recently a corresponding outdoor method for measurements directly in the field has been developed which has to be performed after sunset [5]. For twilight electroluminescence measurements a modified consumer camera without an IR blocking filter is used to detect the emitted $1100 \mathrm{~nm}$ infrared light. The used camera is a Canon EOS 700D with picture shooting times of about $2 \mathrm{~s}$.

\subsection{UV-fluorescence-imaging (UV-F)}

UV-Fluorescence measurements are performed in dark environment (night) by illumination of the PV-modules with UV-light and detection of the fluorescing light in the visible region by the eye or a photographic camera system. In our experimental setup the UV-Fluorescence is detected with a digital photographic camera (Olympus OM D, equipped with high pass filter to cut-off the UVirradiation). Excitation with UV-light is performed with a selfmade UV-lamp consisting of 3 power-tuneable LED-arrays with an emission maximum at $380 \mathrm{~nm}$ (exchangeable to $360 \mathrm{~nm}$ ) and a low pass filter to cut off all visible light. Power supply is a modified DC/DC converter with a controllable and piecewise constant voltage/constant current characteristic, sourced by a 12 cell Lithium-polymer-accumulator with a capacity of $5000 \mathrm{mAh}$. This characterization method is non-destructive, non-invasive, easy to handle and fast (an exposure time of $30 \mathrm{~s}$ is sufficient to achieve a well contrasted UV-fluorescence image of a module).

\subsection{Laboratory tests with test modules}

In order to gain a better understanding of the fluorescence patterns observed in the field, test modules are manufactured, 
Table 1

Hail affected PV plants in comparison.

\begin{tabular}{|c|c|c|c|}
\hline & PV-Plant 1 & PV-Plant 2 & PV-Plant 3 \\
\hline Installation Date & Summer 2014 & Summer 2013 & Summer 2012 \\
\hline PV module type & $250 \mathrm{Wp}$ polycrystalline Si; glass/backsheet & 245 Wp polycrystalline Si; glass/backsheet & $240 \mathrm{Wp}$ polycrystalline $\mathrm{Si}$; glass/backsheet \\
\hline Number of modules & 80 & 510 & 32 \\
\hline System power & $20 \mathrm{kWp}$ & $125 \mathrm{kWp}$ & $7.5 \mathrm{kWp}$ \\
\hline Inverter type & Transformerless, $2 \times 10 \mathrm{kWp}$ three phase & Transformerless, $4 \times 27.6 \mathrm{kWp}$ three phase & HF-Trafo, $3 \times 2 \mathrm{kWp}$ one phase \\
\hline Mounting system type & $12^{\circ}$ flat roof system & $12^{\circ}$ flat roof system & $34^{\circ}$ roof system \\
\hline Orientation & 40 modules south, 20 east, 20 west & south & south \\
\hline $\begin{array}{l}\text { Grounding of substructure \& } \\
\text { module frames/conductor }\end{array}$ & Yes & Yes & Yes \\
\hline Visible damage after hailstorm & 4 modules with glass breakage (5\%) & 3 modules with glass breakage $(0.6 \%)$ & 1 module with glass breakage ( $3 \%)$ \\
\hline Monitoring System & $\begin{array}{l}\text { Inverter based web portal monitoring, } \\
\text { without irradiance measurement } \\
\text { Updated power and yield data every few } \\
\text { minutes }\end{array}$ & $\begin{array}{l}\text { O\&M company with string based monitoring } \\
\text { incl. irradiance measurement }\end{array}$ & $\begin{array}{l}\text { Module based scientific monitoring } \\
\text { installation incl. irradiance measurement } \\
\text { Updated power and yield data every few } \\
\text { minutes }\end{array}$ \\
\hline
\end{tabular}

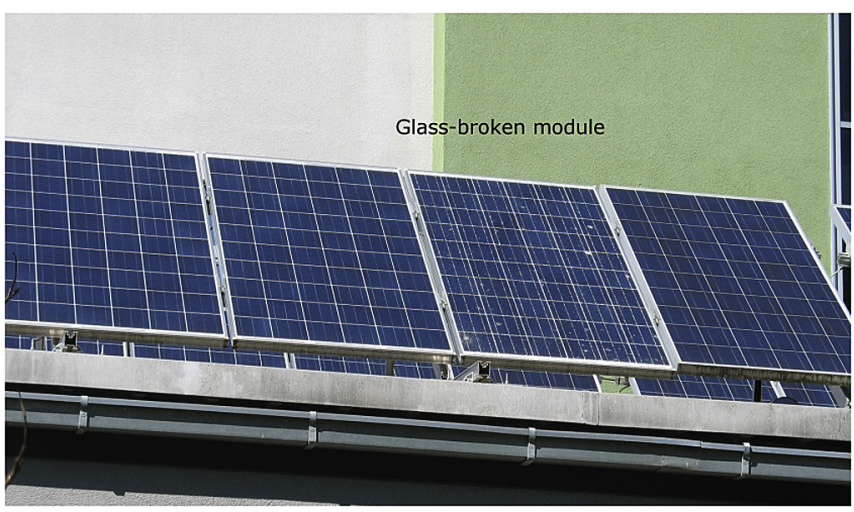

Fig. 1. Module with broken glass after hail storm (plant 3).

partially mechanically treated in order to generate failures (microcracks, glass breakage) and artificially aged in accelerated tests. These mini modules $(2 \times 3 \mathrm{c}$-Si cells $)$ resemble in composition and design standard glass/backsheet modules with EVA encapsulation. Accelerated ageing is performed for $1000 \mathrm{~h}$ under irradiation with artificial sunlight at $1000 \mathrm{~W} / \mathrm{m}^{2}\left(\mathrm{~T}_{\text {chamber }}=60{ }^{\circ} \mathrm{C}\right.$, rel. humidity $=40 \%$ ). An intermediate assessment is performed every $100 \mathrm{~h}$ when UV-fluorescence images are taken of all samples.

\section{Results}

\subsection{Visual inspection and yield data evaluation}

After a heavy hail storm in summer 2015, all three PV power plants showed visible damage with some glass-broken modules: 4 (out of 80), 3 (out of 510) and 1 (out of 32) were affected for plants 1 , 2 and 3, respectively. Modules with broken front glass count as severe/strong damage (Figs. 1 and 2) as this damage has a direct impact on the yield of the PV-plant.

The immediate effect of heavy hail storm can be detected in the monitoring portal of the whole plant 1 (Fig. 3). A loss in the PR of plant 1 of about $10-20 \%$ could be observed directly after the hail event. In other cases, like for plant 2 and 3 , the effect of the storm is inconspicuous in the PR (Figs. 4 and 5).

The broken modules were exchanged shortly after the hail event due to safety and performance reasons. For plant 1 the change was at 21 st of July 2015, for plant 2 the change was at 11th of August 2015.

In system 3, however, the glass-broken module was kept deliberately within the research plant. As plant 3 is equipped with a

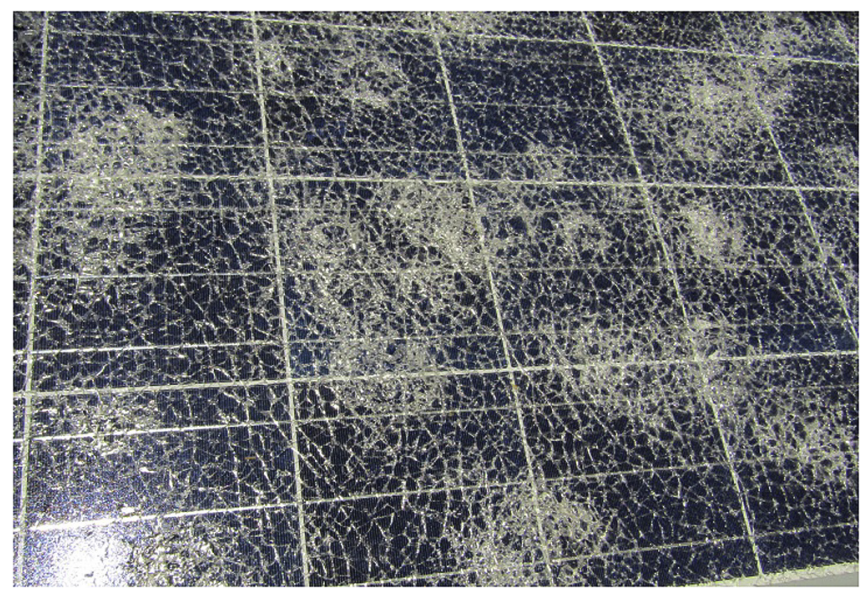

Fig. 2. Module with broken glass after heavy hail storm (plant 1).

module based monitoring system (Solar Edge), it is possible to analyze the effect of the broken glass on the module performance in greater detail and over two years after the hail event (Fig. 6).

Despite a PV module with broken front glass, which is caused by the hail storm, we do not find a drop in the PR of plant 3. Therefore we evaluate the yield of the broken module relative to an undamaged PV module. In Fig. 6 we show the monthly relative yield as quotient of the yield for the glass-broken module to the adjoining reference module. Before the hail storm, the selected two modules showed nearly identical yields with a deviation of only $1-2 \%$ from the expected value. After the hail a drop in the relative yield of $-10 \%$ is observed and in the following an accelerated degradation rate is found for the broken module.

\subsection{Thermography (TG)}

All three power plants are analyzed with thermography in order to find out if damaged modules with broken glass are detectable by their thermographic images (see Figs. 7-9) It can be seen that modules with hail affected damages show no or very little features in their thermographic image when investigated after the hail event.

\subsection{Twilight electroluminescence (TW-EL)}

In the following outdoor EL an UV fluorescence measurements are performed of all three plants in darkness, representative ELimages are given in Figs. 10-12. By analyzing the TW-EL-images 


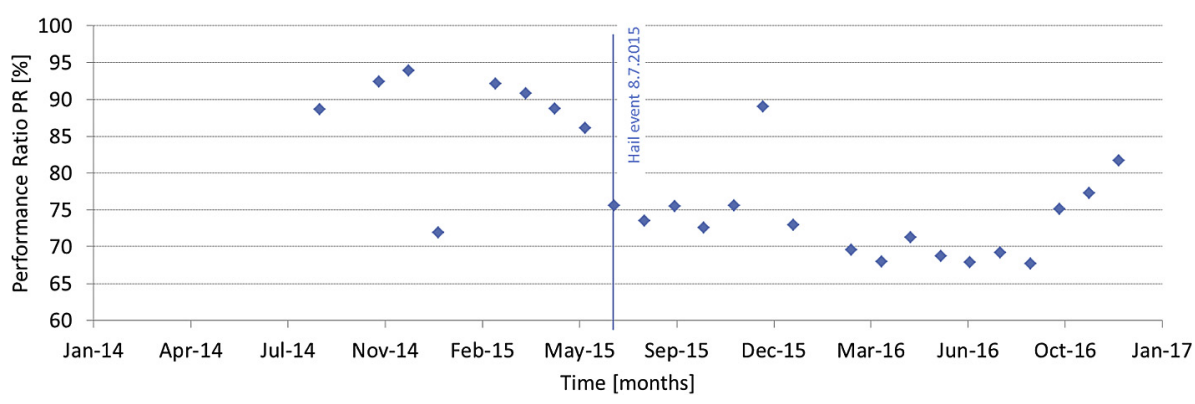

Fig. 3. PR before and after hail event for Plant 1.

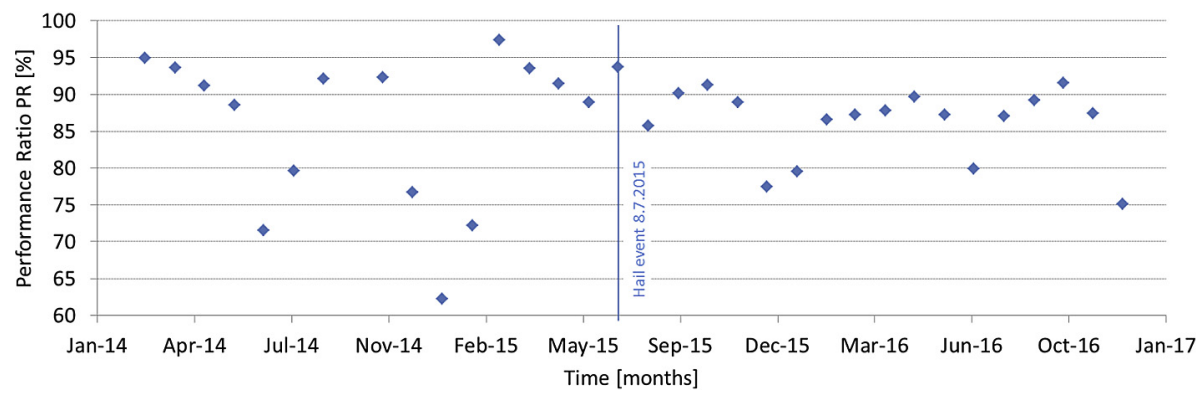

Fig. 4. PR before and after hail event for Plant 2.

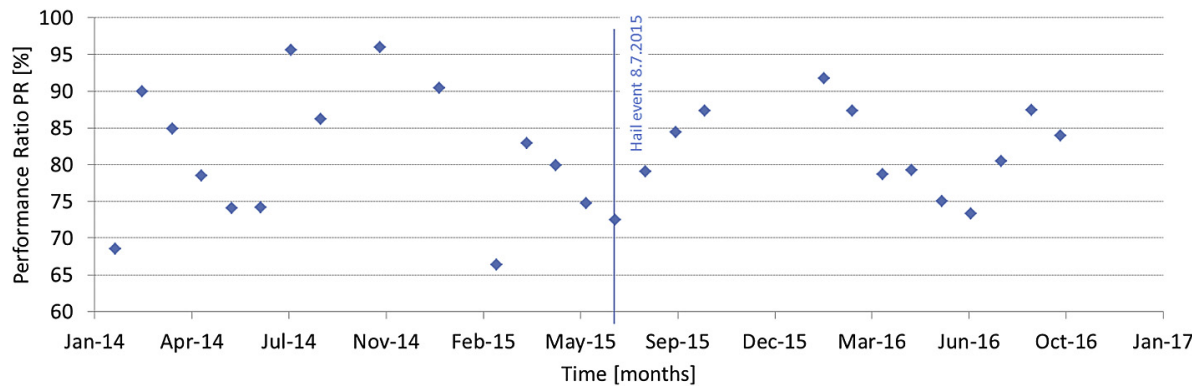

Fig. 5. PR before and after hail event for Plant 3.
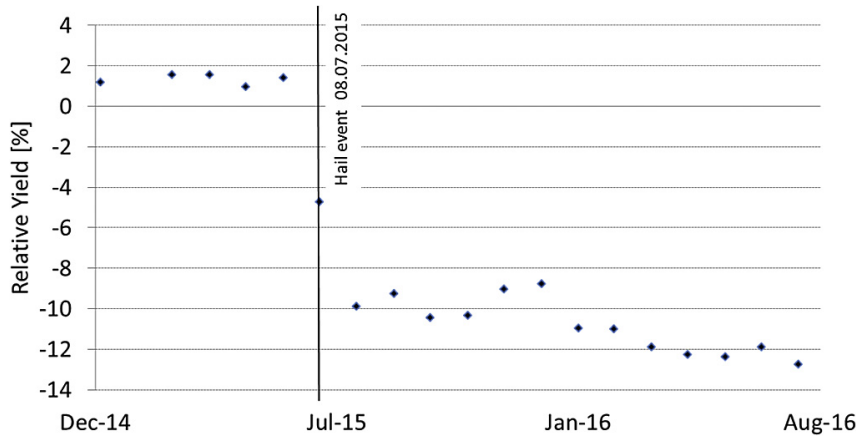

Fig. 6. Yield of a hail affected module relative to a reference module before and after the hail storm (Plant 3). The module front glass broke during the hail storm.

it can be clearly seen that many modules of plant 1 show countless broken cells. Although the glass of these modules is still intact, the cell damage as detected by EL is severe (as shown in Fig. 10) and explains the measured yield, respectively the performance loss of this plant after the hail event. Two sample-modules were taken from the plant and tested in the laboratory with a module flash test

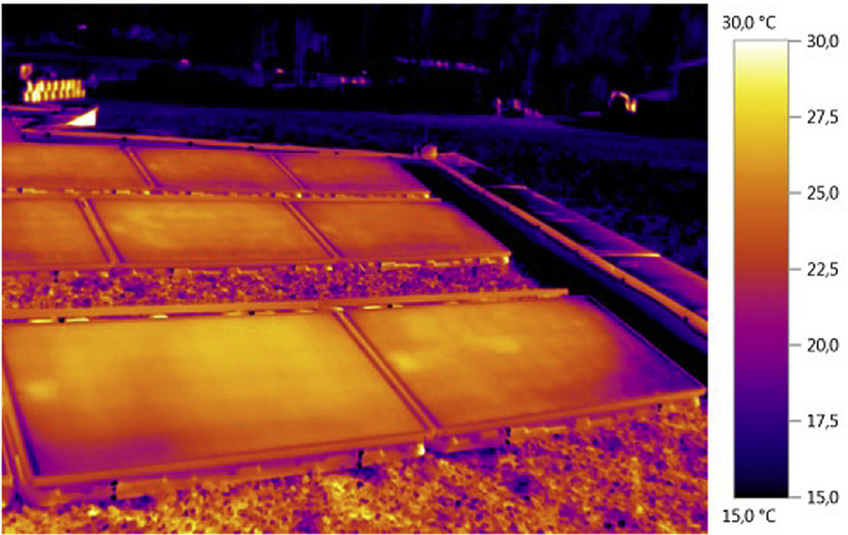

Fig. 7. TG image of plant 1.

system. Sample module one shows a power drop from $250 \mathrm{Wp}$ to $163 \mathrm{Wp}(-35 \%)$ and sample module two from $250 \mathrm{Wp}$ to $177 \mathrm{Wp}$ $(-29 \%)$ relative to the initial flash report.

In contrast, the PV-modules installed in plant 2 showed hardly 


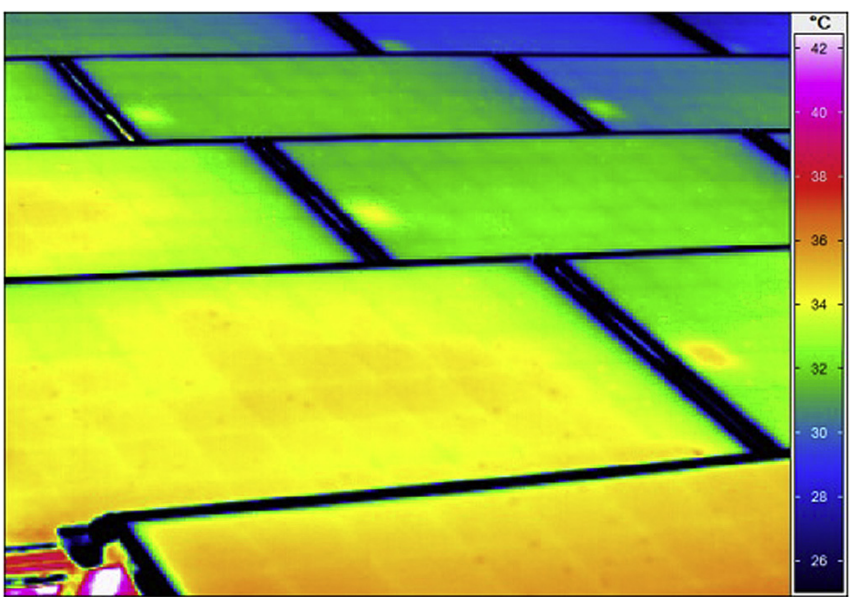

Fig. 8. TG image of plant 2 .

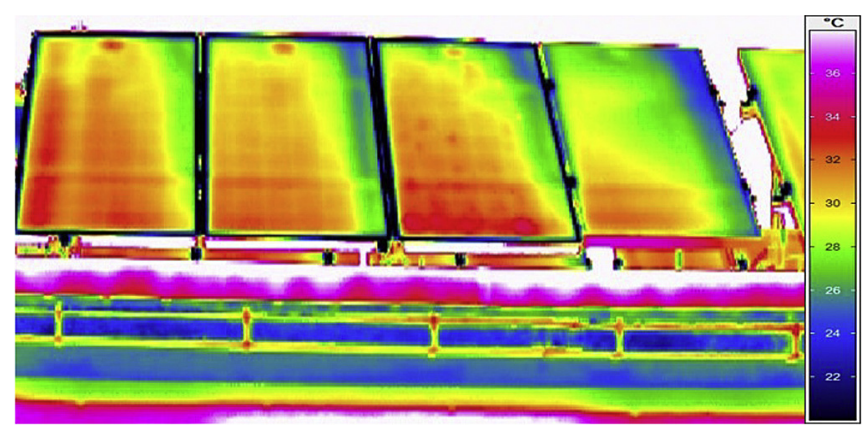

Fig. 9. TG image of plant 3.
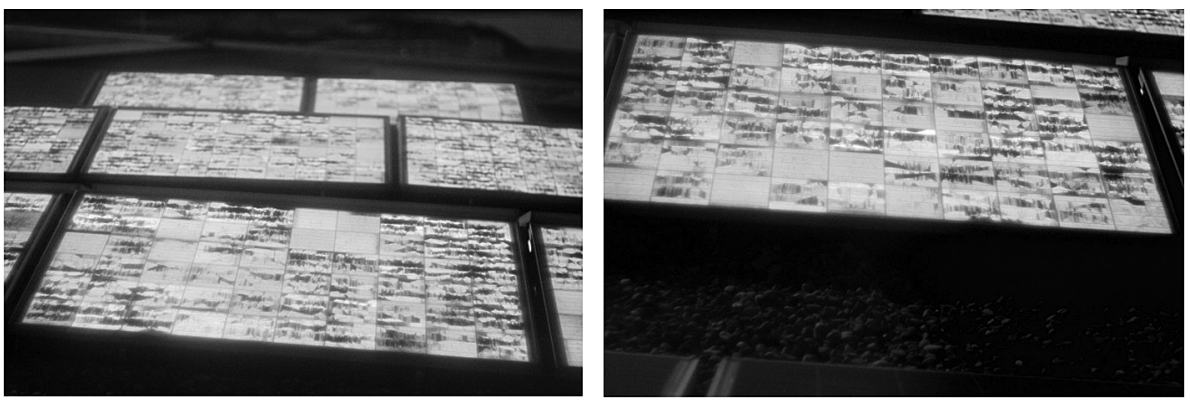

Fig. 10. a, b: TW-EL image of hail affected modules of plant 1 (glass not broken, -30\% power loss due to micro cracks).
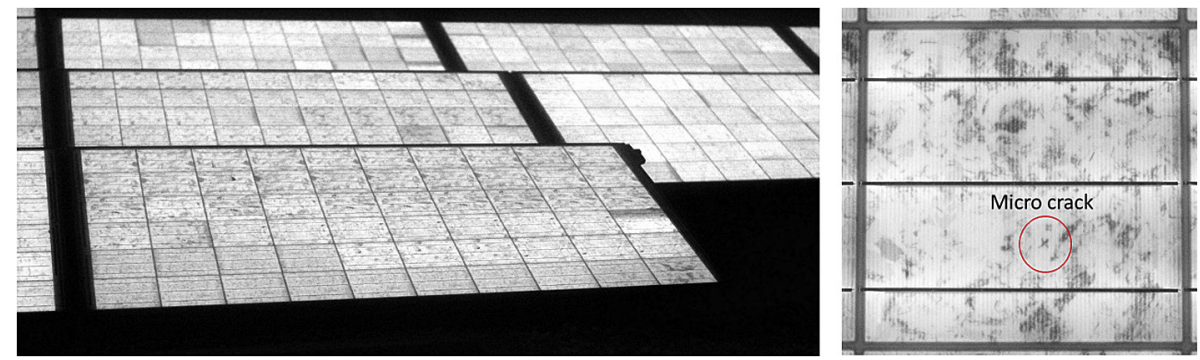

Fig. 11. a, b: TW-EL image of hail affected modules of plant 2 (no loss detectable, only tiny cross micro cracks). 

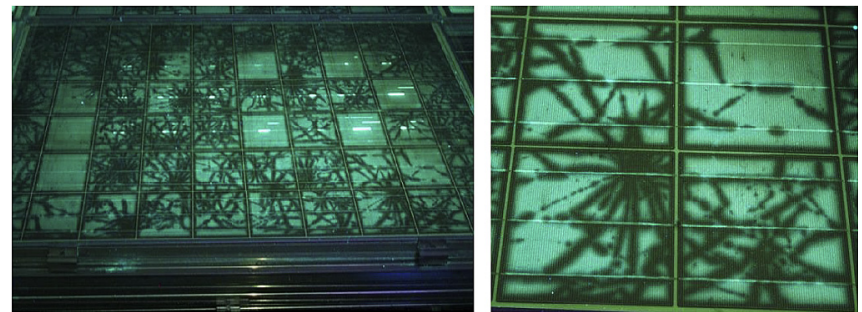

Fig. 13. a,b: UV-F image of a hail damaged module of PV-plant 1 and details with spider web appearance due to micro cracks.
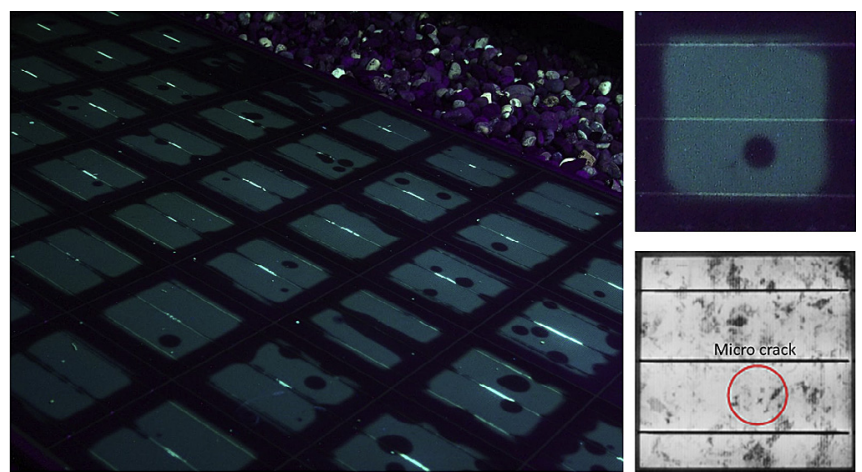

Fig. 14. a,b,c: left: UV-F images of a module in PV-plant 2 and details of one cell with cross-micro crack (UV-F and EL).

reflects the cobweb-shaped cracks in the cells starting from the impact-centre. Next to strongly affected cells with numerous cellcracks also intact cells exist within the same module. The extinctions of the UV-fluorescence above cell cracks allows for the clear visualisation of cell-damages without interfering with the electrical system of the module. The cell cracks visualised with UV-F are in perfect agreement with cell breakages as detected by EL (Fig. 10a, b).

In addition to the line-shaped extinctions of the UV-F above cell
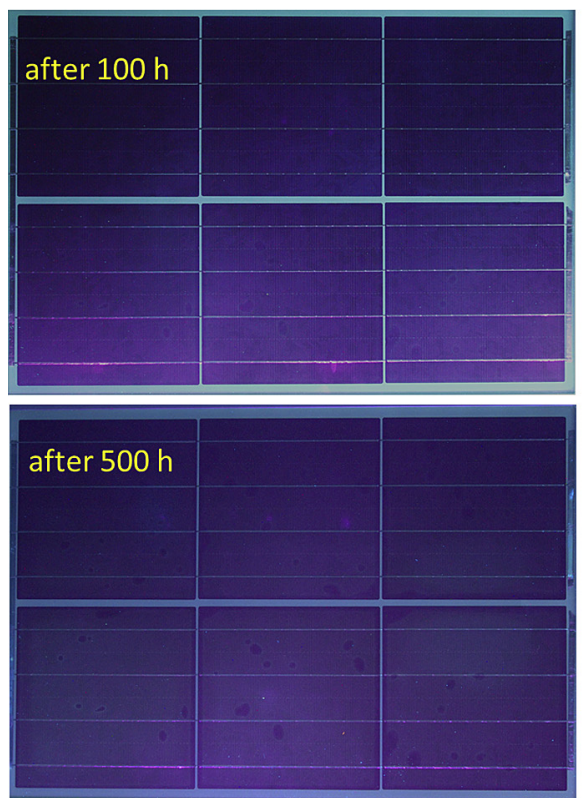

cracks, especially in plant 2 there are several modules found with extraordinary point-shaped extinctions (Fig. 14) of the UV-F which cannot be explained unambiguously at the first sight. Additionally performed high resolution EL-measurements of the effected cells directly in the plant suggest, that small cross-shaped micro-cracks in the cells lead to the extinction-points in the UV-Fluorescence pattern. In order to prove this assumption, an imitation of this effect was performed with specially prepared test modules in accelerated aging tests (see Chapter 3.5).

Additional power measurements on several modules within the investigated PV plants proved, that not all modules with glass breakage show identical behaviour in respect to performance loss, thermographic image and UV- fluorescence. However, a direct correlation exists between the power of the affected modules and the observed EL and UV-F: The more the cell breakage and UV-F tracks, the less the power and performance.

\subsection{Laboratory test to simulate the UV-FL-effects observed}

In order to prove that the point shaped extinctions in the UV-F observed in plant 2 originate from (possibly hail-induced) micro cracks in the cells, test modules were produced and part of them deliberately stressed in order to simulate local mechanical impact. EL proved the formation of micro-cracks (see Fig. 15). These test modules were then subjected to accelerated aging and the development of characteristic UV-F patters is monitored in Fig. 15a-c.

The comparison of the EL and UV-F images in Fig. 16 clearly proves that the point-shaped UV-extinctions originated from crossshaped micro cracks in the cells.

The effect of glass breakage on the formed UV-F pattern is visualised in Fig. 16. Beneath the glass breakage a line shaped extinction of the UV-F takes place, the broadness of the extinction increases with increasing exposure time.

\section{Conclusions}

Three PV plants were inspected with non-destructive characterisation tools after a heavy hail event in July 2015. By comparing the monitoring data and the calculated performance ratios for each

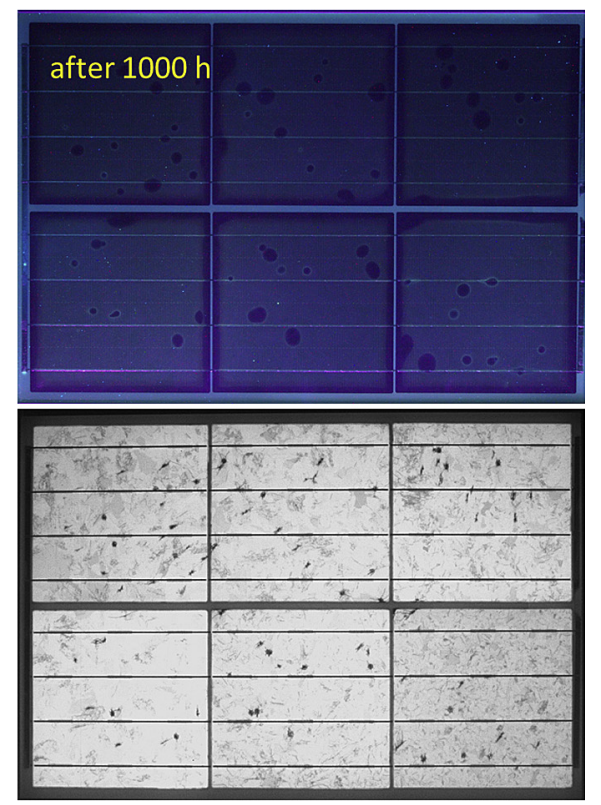

Fig. 15. UV-F images of test module with micro cracks after a) 100, b) 500 and c) $1000 \mathrm{~h}$ of artificial sunlight at $1000 \mathrm{~W} / \mathrm{m}^{2}$ and d) initial EL-image of test module. 

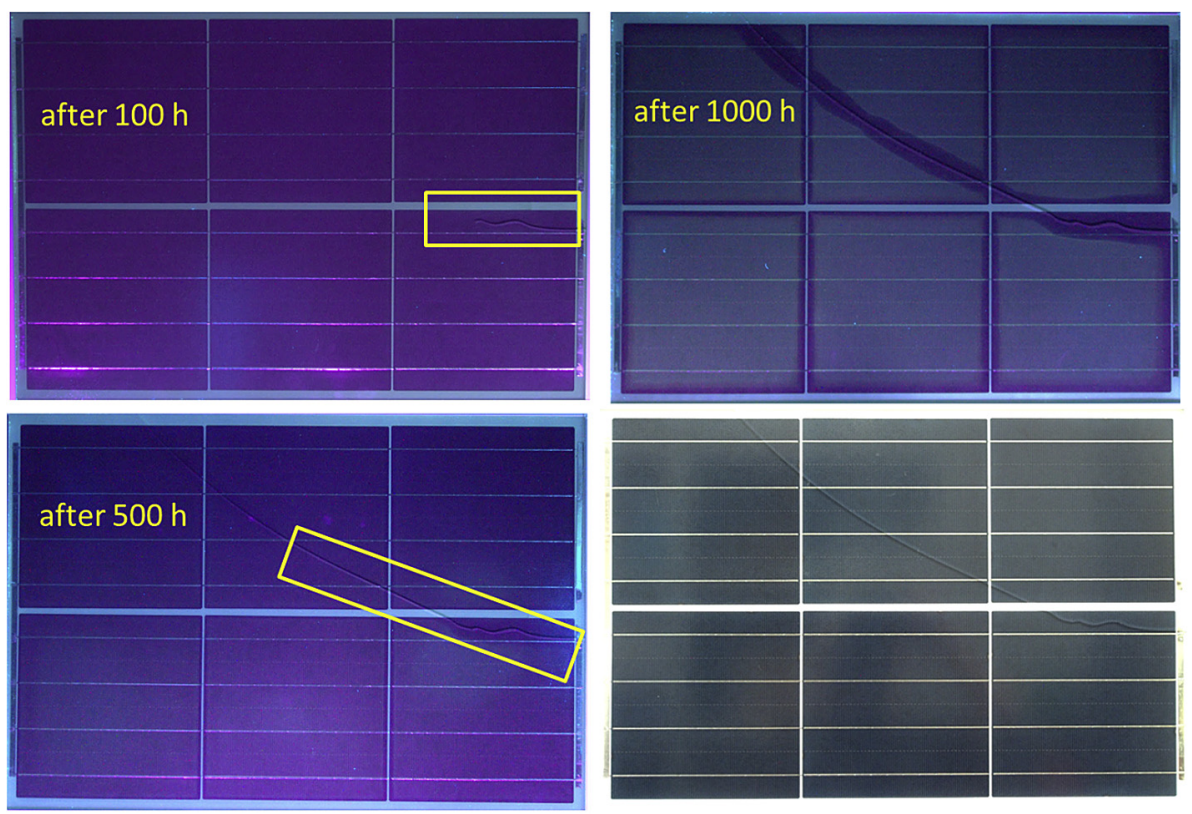

Fig. 16. UV-F images of test module with glass breakage after a) $100 \mathrm{~h}, \mathrm{~b}) 500 \mathrm{~h}$ and c) $1000 \mathrm{~h}$ of an artificial sunlight at $1000 \mathrm{~W} / \mathrm{m}^{2}$ and d) photograph after $1000 \mathrm{~h}$.

plant before and after the hail storm, only one plant (plant 1) showed significant degradation on system level after the exchange of all visually damaged (glass broken) modules with new ones.

Plant 3 showed no significant degradation although one glassbroken module was deliberately kept in the plant over a time of two years after the hail. Thus, on string level, one glass-broken module within a string is sometimes not possible or difficult to identify. However, with a controlling system on module level it could be clearly shown in the monitoring portal that a module with a glass and initiated cell damage is underperforming: the affected module in plant 3 had a performance loss of about $10 \%$ due to the hail impact. In the worst case, modules with complete glass and solar cell breakage exhibit total efficiency losses and in addition impose a high security risk and therefore have to be replaced.

However, there is a strong need to inspect the remaining modules (without glass breakage) directly in the field, in order to assure no damage/partial cell breakages. Further inspection with thermography pointed out that it is difficult to detect hail damaged PV modules. With the aid of two innovative characterisation methods, outdoor electroluminescence and UV-fluorescence imaging, hail-induced damaging of solar cells could be detected even when the solar glass of the modules withstood the mechanical impact of the hailstorm and no damages were visible to the naked eye or well recognizable by thermography. Depending on the degree of damage, completely fractioned cells, line-shaped cracks and small cross shaped micro-cracks were visualized by UV-F imaging and confirmed by EL-measurements. Parallel power measurements confirmed that these "hidden" damages (no visual indication) of affected modules can cause power losses in the range of $30 \%$.

Consequently, the use of the non-destructive, easy to handle and fast characterization techniques UV-fluorescence imaging and electroluminescence allow for the detection and visualisation of hail induced cell damage. Not only obvious damages such as glassbreakage induced cell fracture but also partial cell breakage and micro cracks of otherwise intact modules can be detected. With time, however, these cell defects might even increase in severity leading to severe under-performance of the power plant and, thus, have to be replaced.

\section{Acknowledgement}

This work was conducted as part of the Austrian "Energy Research Program" project INFINITY, funded by the Austrian Climate and Energy Fonds (850414) and the Austrian Research Promotion Agency (FFG), both are gratefully acknowledged.

\section{References}

[1] C. Buerhop, D. Schlegel, M. Niess, C. Vodermayer, R. Weissmann, C.J. Brabec Reliability of IR-imaging of PV-plants under operating conditions, Sol. Energy Mater. Sol. Cells 107 (December 2012) 154-164. https://doi.org/10.1016/j. solmat.2012.07.011.

[2] C. Buerhop-Lutz, H. Scheuerpflug, Characterization of defects in PV-modules by their temperature development using IR-thermography, in: Proceedings of the 31st European Photovoltaic Solar Energy Conference and Exhibition, 5CO.15.3, 2015, pp. 1789-1792, https://doi.org/10.4229/EUPVSEC201520155CO.15.3. Hamburg, Germany.

[3] M. Köntges, S. Kurtz, C. Packard, U. Jahn, K.A. Berger, K. Kato, T. Friesen, H. Liu, M. Van Iseghem, J. Wohlgemuth, D. Miller, M. Kempe, P. Hacke, F. Reil N. Bogdanski, W. Herrmann, C. Buerhop-Lutz, G. Friesen, Review of Failures of Photovoltaic Modules, Report IEA-PVPS T13-01:2014, ISBN 987-3-906042-169, 2014. Source, http://iea-pvps.org/fileadmin/dam/intranet/ExCo/IEA-PVPS T13-01_2014_Review_of_Failures_of_Photovoltaic_Modules_Final.pdf (Downloaded 05.06.2017)

[4] VATh- Guideline, Electrical thermal imaging, Link: http://vath.de/docs/ richtlinien/VATh-Richtlinie_Elektro_NS+PV_engl_web.pdf.

[5] K. Mertens, H. Kösters, M. Diehl, Low-cost-outdoor-EL: cost-efficient extensive on-site quality analysis of solar modules, in: Proceedings of the 31st European Photovoltaic Solar Energy Conference and Exhibition, 5BV.2.42, 2015, pp. 2300-2302, https://doi.org/10.4229/EUPVSEC20152015-5BV.2.42. Hamburg.

[6] M. Köntges, S. Kajari-Schröder, I. Kunze, Crack statistic for wafer-based silicon solar cell modules in the field measured by UV fluorescence, IEEE J. Photovolt 3 (1) (Jan. 2013) 95-101, https://doi.org/10.1109/JPHOTOV.2012.2208941.

[7] A. Morlier, M. Siebert, I. Kunze, G. Mathiak, M. Köntges, Detecting photovoltaic module failures in the field during daytime with ultraviolet fluorescence module inspection, in: Proceedings of 44th IEEE PVSC, June 25-30, 2017. Washington D.C, USA.

[8] A. Morlier, M. Köntges, M. Siebert, I. Kunze, UV fluorescence imaging as fast inspection method for PV modules in the field, in: 14th IEA PVPS Task 13 Meeting, Bolzano, Italy, 2016. Source: http://www.eurac.edu/en/research/ technologies/renewableenergy/conferences/Documents/1_160406_UV\% 20fluorescence\%20in\%20field_Morlier.pdf (Downloaded 03.07.2017).

[9] M. Köntges, S. Kajari-Schröder, I. Kunze, Cells cracks measured by UV fluorescence in the field, in: 27th European Photovoltaic Solar Energy Conference and Exhibition, 4CO.11.4, 2012, pp. 3033-3040, https://doi.org/10.4229/ 27thEUPVSEC2012-4CO.11.4. Munich. 
[10] M. Köntges, I. Kunze, S. Kajari-Schröder, X. Breitenmoser, B. Bjørneklett, Quantifying the risk of power loss in PV modules due to micro cracks, in: Proceedings of the 25th European Photovoltaic Solar Energy Conference and Exhibition, 4BO.9.4, 2010, pp. 3745-3752, https://doi.org/10.4229/25thEUPVSEC2010-4BO.9.4. Valencia, Spain.

[11] M. Köntges, I. Kunze, S. Kajari-Schröder, X. Breitenmoser, B. Bjrneklett, The risk of power loss in crystalline silicon based photovoltaic modules due to microcracks, Sol. Energy Mater. Sol. Cells 95 (2011) 1131-1137.

[12] A.W. Czanderna, F.J. Pern, Encapsulation of PV modules using ethylene viny acetate copolymer as a pottant: a critical review, Sol. Energy Mater. Sol. Cells 43 (2) (1996) 101-181. https://doi.org/10.1016/0927-0248(95)00150-6.

[13] B. Röder, E. Ermilov, D. Philipp, M. Köhl, Observation of polymer degradation processes in photovoltaic modules via luminescence detection, in: SPIE Proceedings Series 7048, Paper 70480F, August 2008, https://doi.org/10.1117/ 12.793795 .

[14] J. Schlothauer, S. Jungwirth, M. Köhl, B. Röder, Degradation of the encapsulant polymer in outdoor weathered photovoltaic modules: spatially resolved inspection of EVA ageing by fluorescence and correlation to electroluminescence, Sol. Energy Mater. Sol. Cells 102 (July 2012) 75-85 https://doi.org/10. 1016/j.solmat.2012.03.022.

[15] J.C. Schlothauer, R.M. Ralaiariso, A. Morlier, M. Köntges, B. Röder, Determination of the cross-linking degree of commercial ethylene-vinyl-acetate polymer by luminescence spectroscopy, J. Polym. Res. 21 (April 2014) 457. https://doi.org/10.1007/s10965-014-0457-9. 